\title{
PENGARUH TERAPI KELUARGA TERHADAP DUKUNGAN KELUARGA DALAM MERAWAT KLIEN DENGAN MASALAH PERILAKU KEKERASAN DI KOTA SURABAYA Pandeirot Marjory Nancye *
}

Akademi Keperawatan William Booth Surabaya, Jln. Cimanuk No. 20 Surabaya

\begin{abstract}
ABSTRAK
Penelitian ini merupakan penelitian dengan desain quasy eksperimen dengan rancangan pre-post test with control group desaign yang bertujuan untuk mengetahui pengaruh terapi keluarga terhadap dukungan keluarga dalam merawat klien dengan perilaku kekerasan di kota Surabaya. Populasi penelitian ini adalah keluarga klien dengan masalah perilaku kekerasan di kota Surabaya. Jumlah sampel dalam penelitian ini sebanyak 48 keluarga dan untuk menentukan kelompok subyek yang menjadi responden kelompok intervensi dan kelompok kontrol digunakan Stratified purposive random sampling. Untuk menguji pengaruh terapi keluarga terhadap dukungan keluarga digunakan Paired sample $T$ Test dan Independent-Sample T Test. Hasil penelitian menunjukkan bahwa keluarga yang mendapat intervensi terapi keluarga menunjukkan peningkatan dukungan dalam merawat klien dengan masalah perilaku kekerasan. Hasil analisa beda dua mean menunjukkan perbedaan yang signifikant antara rata-rata hasil post tes dari kelompok intervensi dan kelompok kontrol yang ditunjukkan dengan $\quad \mathrm{p}$ value $=0,001$ yang artinya terdapat perbedaan sangat signifikan antara terapi keluarga terhadap dikungan keluarga. Penelitian ini menyimpulkan bahwa pengaruh terapi keluarga sangat signifikant terhadap dukungan keluarga dalam merawat klien dengan masalah perilaku kakerasan. Hal ini dapat terjadi karena ketidak mampuan keluarga dalam menjalankan fungsi keluarga dapat menjadi faktor penyebab ketidak mampuan keluarga merawat anggota keluarga dengan masalah perilaku kekerasan. Untuk itu pelayanan keperawatan perlu meninjau kembali aspek yang dapat meningkatkan kemampuan keluarga serta memfasilitasi keluarga untuk dapat menjalankan fungsinya khususnya fungsi pelayanan kesehatan dalam keluarga.
\end{abstract}

Kata kunci : Terapi Keluarga, Dukungan Keluarga, Merawat, Perilaku Kekerasan

\section{Pendahuluan}

Kesehatan jiwa merupakan suatu kondisi yang memungkinkan perkembangan fisik, intelektual, emosional yang optimal dari seseorang dan perkembangan itu berjalan selaras dengan orang lain. Namun sebaliknya apabila seseorang itu mengalami gangguan dalam jiwanya, maka orang tersebut akan mengalami perubahan perilaku yang dapat berlangsung lama. Sekitar satu persen penduduk dunia akan mengidap skizofrenia pada suatu waktu dalam hidupnya. Angka kejadian gangguan jiwa menurut penelitian WHO dalam masyarakat berkisar satu sampai tiga permil penduduk, jadi apabila suatu daerah dengan jumlah penduduk lebih kurang 30 juta, maka akan ada sebanyak 30.00090.000 penderita psikotik. Bila $10 \%$ dari penderita perlu pelayanan perawatan psikiatrik, maka akan ada 3.000-9.000 yang harus dirawat. (Suara merdeka, 2005) Di
Indonesia diperkirakan $1 \%$ - $2 \%$ penduduk atau sekitar dua sampai empat juta jiwa akan terkena penyakit ini. Bahkan sekitar sepertiganya kini sedang mengidap skizofrenia (Chandra, 2005).

Suatu studi telah menunjukkan seseorang yang mempunyai hubungan yang dekat dengan penderita skizofrenia mempunyai kesempatan 1 dalam 10 anggota keluarga lainnya yang juga akan mengalami gangguan jiwa. Hal ini menunjukkan faktor stuktur keluarga, genetik dan biochemical dipercayai berkombinasi dalam menentukan mudahnya/rapuhnya (vulnerability) individu untuk mengalami skizofrenia. Salah satu bentuk gangguan jiwa adalah masalah perilaku kekerasan, dimana perilaku kekerasan (perilaku agresif/perilaku amuk), dinyatakan oleh Aleksander (1991) sebagai suatu kondisi yang dapat terjadi karena 
perasaan marah, cemas, tegang, bersalah, frustasi dan permusuhan.

Penyebab dari perilaku kekerasan dapat disebabkan halusinasi (dengar, lihat dan taktil), alkohol, drug abuse, delusi, penyakit alzheimer, ancaman dari lingkungan dan lainlain. Menurut Straznickas, McNeil, \& Binder (1993, dalam Mohr, 2006) faktor keluarga merupakan salah satu faktor yang dapat menimbulkan perilaku kekerasan pada seseorang dan diperberat dengan anggapan di masyarakat terdapat stigma bahwa gangguan jiwa merupakan penyakit yang sulit disembuhkan, memalukan dan merupakan aib keluarga (Maramis, 1995).

Setelah mengetahui adanya penyakit dalam keluarga terutama penyakit atau gangguan jiwa seringkali menjadikan keluarga merasakan beban lebih berat, hal ini disebabkan perilaku atau reaksi klien yang berlebihan seperti menjadi apatis, menarik diri, halusinasi, dan perilaku kekerasan. Dihari-hari awal anggota keluarga merasa bingung dan marah bahkan dapat menyalahkan serta memojokkan klien. Hal ini dapat menyebabkan depresi, kemarahan dan timbul penyakit psikosomatik pada klien (Dozz, 2005). Ketidaksiapan keluarga dalam menghadapi masalah ini menjadikan keluarga memberikan respon yang tidak efektif pada klien. Sebagian dari cara keluarga mereduksi perasaan-perasaan tertekan, kecemasan, stress atau konflik adalah dengan menggunakan mekanisme pertahanan diri baik yang ia lakukan secara sadar atau tidak sadar.

Semua anggota keluarga saling mempengaruhi satu dan lainnya melalui interaksi dan saling memberikan support dalam memperlihatkan fungsi dasar yang perlu untuk kesejahteraan keluarga. Jika keluarga memiliki pengaruh yang positif pada anggotanya, mereka akan mempunyai rasa dan pengakuan diri serta harga diri yang positif, dan akan menjadi produktif sebagai anggota masyarakat. Namun pada kenyataannya bahkan keluarga sering merupakan faktor pencetus timbulnya masalah kesehatan mental klien termasuk didalamnya pencetus timbulnya perilaku kekerasan klien yang digambarkan keluarga seringkali bersikap enggan untuk membawa klien pulang ke rumah dari rumah sakit, sehingga jika klien diharuskan pulang maka keluarga sering memperlakukan klien dengan tidak baik dan tidak mendukung perawatan klien dirumah. Hal ini sebagai akibat sikap keluarga yang tidak terapeutik terhadap klien dan kurangnya pengetahuan mengenai peran serta keluarga dalam perawatan klien, ketidakmampuan memahami keadaan klien, yang pada akhirnya memperberat keadaan klien yang belum pernah dirawat, dan penyebab kekambuhan klien pasca opnamel keluar rumah sakit.

Menurut Keliat (1996) kekambuhan pada klien ganggun jiwa disebabkan oleh beberapa faktor yaitu klien, tenaga medis, tenaga perawat dan dari keluarga sendiri. Selanjutnya dikatakan apabila seseorang yang mengalami gangguan jiwa mempunyai kemampuan adaptasi yang baik selama di rumah daripada di rumah sakit sebaiknya klien dirawat di rumah karena akan lebih mendapat dukungan dan perawatan dari keluarga. Kekambuhan ini dapat dicegah dan diantisipasi dengan melibatkan keluarga dalam perawatan klien dirumah melalui psikoedukasi dan psikoterapi yang diberikan pada keluarga, yang salah satunya adalah dengan terapi keluarga.

Terapi keluarga (family therapy) adalah suatu teknik yang digunakan untuk sebuah pendekatan psikoterapi yang membantu anggota keluarga mencapai pengertian yang mendalam dalam mengatasi permasalahan mereka dan merubah perilaku serta emosi dari yang disfungsi ke arah yang lebih sehat. Dengan menggunakan metode ini, keluarga dapat memperlihatkan perlunya dasar dari fungsi untuk menyehatkan seluruh anggota keluarga. Sehingga terapi ini diperuntukkan bagi keluarga yang tidak mampu memperlihatkan fungsi dasar ini secara adekuat (Shives, 1998). Didalam laporan kejadian pelaksanaan terapi keluarga yang dilaporkan oleh Straton dari Leed Family Therapy dan Research Centre dikatakan bahwa pelaksanaan terapi keluarga sangat efektif untuk menolong seseorang dengan masalah yang sangat kompleks dengan rentang yang sangat bervariasi, mulai dari masalah kondisi anak seperti gangguan perasaan, gangguan makan, dan kenakalan remaja, masalah pada orang dewasa dan masalah psikiatri, seperti schizophrenia. (Stratton, 2005). Fokus dari terapi ini, bukan individual, namun pada keluarga secara keseluruhan. Konsep dasar dari bentuk penatalaksanaannya adalah lebih cepat, lebih 
logis, lebih menguntungkan, dan lebih ekonomis untuk memperlakukan semua anggota keluarga dalam suatu sistem hubungan dibanding konsentrasi hanya secara individual yang diduga dibutuhkan dalam penatalaksanaan (Goldenberg \& Goldenberg, 1995: Townsend, 2005). Ada beberapa tahap yang dilakukan dalam terapi keluarga yaitu tahap pengkajian awal, tahap intervensi dan tahap terminasi (Shives, 1998), dan tahap pengikatan dan motivasi, tahap perubahan perilaku dan tahap generalisasi (Sexton dan Alexander, dalam Wilson, 2000) yang pelaksanaannya dilakukan secara berurutan, terorganisir dan mempertahankan fokus pada inti permasalahan keluarga dan individu.

Berdasarkan pengalaman peneliti selama praktek klinik keperawatan di Rumah Sakit Dr. Marzoeki Mahdi Bogor dan di Rumah Sakit Jiwa Daerah Menur Surabaya, pada kenyataannya terapi keluarga ini belum dilakukan baik kepada keluarga yang anggota keluarganya masih dirawat di rumah sakit terlebih bagi keluarga yang anggota keluarganya telah keluar dari rumah sakit. Demikian juga berdasarkan pengalaman klinik keperawatan kesehatan jiwa masyarakat di Kecamatan Sindang Barang Bogor, ternyata banyak keluarga yang memiliki anggota keluarga dengan gangguan jiwa tetapi tidak terdeteksi pusat pelayanan kesehatan setempat.

Menurut data di Rumah Sakit Jiwa Daerah Menur Surabaya bahwa jumlah penderita gangguan jiwa di kota Surabaya cukup besar, didukung pula Surabaya merupakan kota metropolitan kedua di Indonesia setelah Jakarta yang sangat beresiko meningkatnya angka kekambuhan bahkan meningkat juga jumlah klien baru yang disebabkan tingkat stressor yang tinggi dan salah satu penyebabnya adalah dukungan keluarga yang belum maksimal pada klien karena belum dilakukan terapi keluarga secara khusus pada keluarga terutama yang ada di rumah atau di masyarakat, sehingga intervensi terapi keluarga yang akan dilakukan diharapkan bermanfaat bagi keluarga yang merawat anggota keluarga yang mengalami gangguan jiwa khususnya masalah perilaku kekerasan diwilayah kota Surabaya.

Rumah Sakit Jiwa Menur Surabaya adalah salah satu rumah sakit jiwa daerah di propinsi Jawa Timur yang juga merupakan salah satu rumah sakit rujukan kesehatan jiwa untuk Indonesia bagian Timur. Baik klien yang rawat jalan maupun yang pasca opname/KRS, mereka akan kembali kerumah bersama dengan keluarga, sehingga dapat diperkirakan akan meningkat juga jumlah klien dan keluarga yang memerlukan perawatan, psikoedukasi, dan intervensi terapi keluarga di rumah.

\section{Metode}

Penelitian ini menggunakan metode intervensi semu (quasi experiment) dengan rancangan pre-post test with control group design untuk mengetahui pengaruh terapi keluarga terhadap dukungan keluarga dalam merawat klien dengan masalah perilaku kekerasan. Responden penelitian dibagi dalam dua kelompok yaitu kelompok intervensi (perlakuan) dan kelompok kontrol (tanpa perlakukan) kemudian intervensi terapi keluarga diberikan pada kelompok intervensi, sedangkan kelompok kontrol tidak mendapatkan intervensi terapi keluarga, tetapi tetap diberikan terapi generalis setelah penelitian. Populasi pada penelitian ini adalah keluarga klien dengan masalah perilaku di wilayah kerja Dinas Kesehatan Kota Surabaya dengan dengan sampel sejumlah 24 responden sebagai kelompok intervensi dan 24 responden sebagai kelompok kontrol menggunakan Stratified purposive random sampling. Variabel terikat yang diukur adalah perbedaan dukungan keluarga dalam merawat klien dengan masalah perilaku kekerasan.

\section{Hasil \& Pembahasan}

A. Gambaran Karakteristik Responden Keluarga Yang Memiliki Anggota Keluarga Dengan Masalah Perilaku Kekerasan pada kelompok Intervensi dan Kelompok Kontrol

\section{Distribusi Frekuensi Responden}

Tabel 2 Distribusi Berdasarkan

Karakteristik Jenis Kelamin, Pendidikan, Pekerjaan, Hubungan Keluarga Seluruh Responden Keluarga Yang Merawat Klien Dengan Masalah Perilaku Kekerasan di Kota Surabaya,Tahun 2007 $(\mathrm{n}=48)$ 


\begin{tabular}{|l|c|c|}
\hline \multicolumn{1}{|c|}{ Variabel } & Jumlah & Persentase \\
\hline Jenis Kelamin & & \\
Laki-laki & 17 & 35,4 \\
Perempuan & 31 & 64,6 \\
Total & $\mathbf{4 8}$ & $\mathbf{1 0 0}$ \\
& & \\
Pendidikan & & \\
Tidak Sekolah & 4 & 8,3 \\
Sekolah Dasar & 7 & 14,6 \\
SMP & 13 & 27,1 \\
SMA & 20 & 41,7 \\
Perguruan Tinggi & 4 & 8,3 \\
Total & $\mathbf{4 8}$ & $\mathbf{1 0 0}$ \\
& & \\
Pekerjaan & & \\
Tidak Bekerja & 13 & 27,1 \\
Pegawai negri & 3 & 6.3 \\
Pegawai Swasta & 14 & 29,2 \\
Wiraswasta & 18 & 37,5 \\
Total & $\mathbf{4 8}$ & $\mathbf{1 0 0}$ \\
& & \\
& & \\
Hubungan & & \\
Keluarga & & \\
Orang Tua & 24 & 50,0 \\
Saudara kandung & 15 & 31,2 \\
Suami/Istri & 9 & 18,8 \\
Total & $\mathbf{4 8}$ & $\mathbf{1 0 0}$ \\
& & \\
\hline
\end{tabular}

Berdasarkan tabel 2 Jenis kelamin responden sebagian besar adalah perempuan yaitu sebanyak $31(64,6 \%)$ orang. Tingkat pendidikan responden yang banyak 20 dari $48(41,7 \%)$ orang adalah berpendidikan ting kat SMU. Paling banyak pekerjaan rsponden adalah wiraswasta sebanyak 18 dari 48 (37,5 $\%)$ orang. Pekerjaan responden. Hubungan keluarga antara responden dengan anggota keluarga yang mengalami masalah perilaku kekerasan sebagian adalah orang tua klien sebanyak 24 dari $48(50,0 \%)$.

\section{Menganalisa Kesetaraan Karakteristik} Responden Keluarga yang memiliki Angota Keluarga dengan masalah Perilaku Kekerasan.

Tabel 3 Distribusi Responden Berdasarkan Karakteristik Umur Keluarga Yang Merawat Klien Dengan Masalah Perilaku Kekerasan Pada Kelompok Intervensi Dan Kelompok Kontrol di Kota Surabaya,Tahun 2007 (n $=48$ )

\begin{tabular}{|l|c|c|c|c|c|}
\hline Variabel & $\mathbf{n}$ & Mean & Median & SD & p Value \\
\hline Umur & & & & & \\
& 2 & 49,13 & 51,50 & 11, & 0,776 \\
Intervensi & 4 & 50,17 & 48,50 & 685 & \\
& 2 & & & 13, & \\
Kontrol & 4 & & & 490 & \\
\hline
\end{tabular}

Nilai rata-rata umur kelompok intervensi adalah 49,13 dengan standar deviasi 11,658. Sedangkan untuk umur kelompok kontrol rata-rata adalah 50,17 dengan standar deviasi 13,490. Hasil uji Levene's diatas didapatkan nilai $\mathrm{p}=0,776$, berarti varian kedua kelompok karaktristik umur baik kelompok intervensi maupun kelompok kontrol adalah sama atau setara. 
Tabel 4 Distribusi Berdasarkan Karakteristik Jenis Kelamin, Pendidikan, Pekerjaan, Hubungan Keluarga Responden Keluarga Yang Merawat Klien Dengan Masalah Perilaku Kekerasan Pada Kelompok Intervensi Dan Kelompok Kontrol di Kota Surabaya, Tahun 2007 ( $\mathrm{n}=48$ )

\begin{tabular}{|c|c|c|c|c|c|c|c|}
\hline \multicolumn{8}{|c|}{ Golongan Kelompok Responden } \\
\hline \multirow[t]{2}{*}{ Karakteristik Responden } & \multicolumn{2}{|c|}{$\begin{array}{l}\text { Kelompok } \\
\text { Kontrol } \\
(\mathbf{n}=\mathbf{2 4})\end{array}$} & \multicolumn{2}{|c|}{$\begin{array}{c}\text { Kelompok } \\
\text { Intervensi } \\
(\mathbf{n}=\mathbf{2 4})\end{array}$} & \multicolumn{2}{|c|}{ Total } & \multirow[t]{2}{*}{$P$ value } \\
\hline & $\mathbf{N}$ & $\%$ & $\mathbf{N}$ & $\%$ & $\mathbf{N}$ & $\%$ & \\
\hline Jenis Kelamin & & & & & & & \multirow{8}{*}{0,841} \\
\hline Laki-laki & 9 & 52,9 & 8 & 47,1 & 17 & 100 & \\
\hline Perempuan & 15 & 48,4 & 16 & 51,6 & 31 & 100 & \\
\hline \multicolumn{8}{|l|}{ Pendidikan } \\
\hline Tidak Sekolah & 2 & 8,3 & 2 & 8,3 & 4 & 100 & \\
\hline Sekolah Dasar & 4 & 16,7 & 3 & 12,5 & 7 & 100 & \\
\hline SMP & 6 & 25,0 & 7 & 29,2 & 13 & 100 & \\
\hline SMU & 9 & 37,5 & 11 & 45,8 & 20 & 100 & \\
\hline Perguruan Tinggi & 3 & 12,5 & 1 & 4,2 & 4 & 100 & \\
\hline \multicolumn{8}{|l|}{ Pekerjaan } \\
\hline Tidak Bekerja & 3 & 12,5 & 10 & 41,7 & 13 & 100 & \multirow{4}{*}{0,540} \\
\hline Pegawai Negri & 3 & 12,5 & 0 & 0 & 3 & 100 & \\
\hline Pegawai Swasta & 7 & 29,2 & 7 & 29,2 & 14 & 100 & \\
\hline Wiraswasta & 11 & 45,8 & 7 & 29,2 & 18 & 100 & \\
\hline \multicolumn{8}{|l|}{ Hubungan Keluarga } \\
\hline Orang Tua & 12 & 50,0 & 12 & 50,0 & 24 & 100 & \multirow{4}{*}{0,449} \\
\hline Saudara Kandung & 9 & 37,5 & 6 & 25,0 & 15 & 100 & \\
\hline Suami/Istri & 3 & 12,5 & 6 & 25,0 & 9 & 100 & \\
\hline Lain-lain & 0 & 0,00 & 0 & 0,00 & 0 & 100 & \\
\hline
\end{tabular}

Berdasarkan tabel 2 Jenis kelamin responden baik kelompok intervensi sebanyak 15 dari $24(62,5 \%)$ maupun kelompok kontrol sebanyak 16 dari $24(66,7 \%)$ responden sebagian besar adalah perempuan. Tingkat pendidikan responden baik kelompok intervensi sebanyak 9 dari $24(39,5 \%)$ maupun kelompok kontrol sebanyak 11 dari $24(45,8 \%)$ responden menunjukkan yang paling banyak tingkat pendidikan SMU. Pekerjaan kelompok intervensi paling banyak adalah wiraswasta sebanyak 11 dari 24 (45,8 $\%)$ sedangkan pada kelompok kontrol paling banyak responden yang tidak bekerja sebanyak 10 dari $24(41,7 \%)$ responden. Hubungan keluarga antara responden dengan anggota keluarga yang mengalami masalah perilaku kekerasan baik kelompok intervensi sebanyak 12 dari $24(50,0 \%)$ maupun kelompok kontrol sebanyak 12 dari 24 (50,0
$\%$ ) responden paling banyak adalah orang tua. Hasil uji statistik menunjukkan karakteristik kelompok intervensi dan kelompok kontrol setara dalam hal usia, jenis kelamin, tingkat pendidikan, pekerjaan dan hubungan keluarga, ditunjukkan setiap karakter memiliki $\mathrm{p}$ value $>0,05$.

\section{B. Dukungan Keluarga Dalam Merawat Klien Dengan Masalah Perilaku Kekerasan
1. Uji Analisis Kesetaraan Dukungan Keluarga sebelum dilakukan Intervensi Terapi Keluarga

Tabel 5 Distribusi Responden Berdasarkan Rata-rata Nilai Dukungan Keluarga Pengukuran Pertama Pada Kelompok 
Intervensi dan Kontrol Di Kota Surabaya, Tahun 2007 (n=48)

\begin{tabular}{|l|c|c|c|c|c|}
\hline $\begin{array}{c}\text { Nilai } \\
\text { Dukungan }\end{array}$ & N & Mean & SD & SE & $\begin{array}{c}\text { P } \\
\text { value }\end{array}$ \\
\hline $\begin{array}{l}\text { Pengukuran } \\
\text { Pertama } \\
\begin{array}{c}\text { Intervensi } \\
\text { Kontrol }\end{array}\end{array}$ & 24 & 59,50 & 9,250 & 1,914 & 0,863 \\
\hline
\end{tabular}

Nilai rata-rata dukungan kelompok intervensi adalah 59,50 dengan standar deviasi 9,250. Sedangkan untuk nilai dukungan kelompok kontrol rata-rata nilai dukungannya adalah
59,04 dengan standar deviasi 9,038. Hasil uji Levene's diatas didapatkan nilai $\mathrm{p}=0,863$, berarti varian kedua kelompok yaitu dukungan keluarga pada pengukuran pertama (pre tes) baik kelompok intervensi maupun kelompok kontrol adalah sama.

\section{Pengaruh Terapi Keluarga Terhadap Dukungan Keluarga Dalam Merawat Klien Dengan masalah Perilaku Kekerasan.}

Tabel 6. Distribusi Responden Berdasarkan Rata-rata Nilai Dukunga Keluarga Pengukuran Pertama Pada Kelompok Intervensi dan Kontrol Di Kota Surabaya, Tahun 2007 (n = 48)

\begin{tabular}{|c|c|c|c|c|c|c|}
\hline No. & Nilai Dukungan & $\mathbf{N}$ & Mean & SD & SE & P value \\
\hline \multirow[t]{5}{*}{1.} & Dukungan Emosi & & & & & \\
\hline & Pre.Intervensi & 24 & 13,63 & 2,990 & 0,610 & 0,001 \\
\hline & Post. Intervensi & 24 & 35,08 & 1,139 & 0,232 & \\
\hline & Pre.Kontrol & 24 & 13,96 & 3,237 & 0,661 & 0,720 \\
\hline & Post Kontrol & 24 & 13,67 & 3,002 & 0,613 & \\
\hline \multirow[t]{5}{*}{2.} & Dukungan .Penghargaan & & & & & \\
\hline & Pre. Intervensi & 24 & 12,83 & 2,884 & 0,589 & 0,000 \\
\hline & Post. Intervensi & 24 & 31,75 & 0,847 & 0,173 & \\
\hline & Pre.Kontrl & 24 & 13,79 & 3,257 & 0,665 & 0,440 \\
\hline & Post.Kontrol & 24 & 14,13 & 3,603 & 0,736 & \\
\hline \multirow[t]{5}{*}{3.} & Dukungan Informasi & & & & & \\
\hline & Pre. Intervensi & 24 & 17,42 & 3,063 & 0,625 & 0,000 \\
\hline & Post Intervensi & 24 & 38,42 & 1,640 & 0,335 & \\
\hline & Pre Kontrol & 24 & 17,71 & 3,770 & 0,770 & 0,324 \\
\hline & Post.Kontrol & 24 & 17,25 & 2,908 & 0,594 & \\
\hline \multirow[t]{5}{*}{4.} & Dukungan Instrumental & & & & & \\
\hline & Pre. Intervensi & 24 & 15,63 & 3,076 & 0,628 & 0,001 \\
\hline & Post. Intervensi & 24 & 31,58 & 0,654 & 0,133 & \\
\hline & Pre. Kontol & 24 & 13,58 & 2,041 & 0,417 & 0,038 \\
\hline & Post. Kontrol & 24 & 13,79 & 2,449 & 0,500 & \\
\hline
\end{tabular}

Rata-rata nilai dukungan emosi pada kelompok intervensi pada pengukuran pertama (pre test) adalah 13,63 dengan standar deviasi 2,990. Pada pengukuran kedua (post test) didapat rata-rata nilai dukungan adalah 35,08 dengan standar deviasi 1,139. Terlihat mean perbedaan antara pengukuran pertama dan kedua adalah 21,45 dengan standar deviasi $-1,851$. Hasil uji statistik didapatkan nilai $\mathrm{p}=0,001$ maka dapat disimpulkan ada perbedaan signifikan antara nilai dukungan emosi keluarga pada pengukuran pertama dan kedua kelompok intervensi. Dari analisis dapat dikatakan bahwa ada peningkatan dukungan emosi responden. Rata-rata nilai dukungan penghargaan pada kelompok intervensi pada pengukuran pertama adalah 12,83 dengan 
standar deviasi 2,884. Pada pengukuran kedua didapat rata-rata nilai dukungan adalah 31,75 dengan standar 0,847 . Terlihat mean perbedaan antara pengukuran pertama dan kedua adalah 18,92 dengan standar deviasi 2,037. Hasil uji statistik didapatkan nilai $\mathrm{p}=$ 0,000 maka dapat disimpulkan ada perbedaan signifikan antara nilai dukungan penghargaan keluarga pada pengukuran pertama dan kedua kelompok intervensi. Dari analisis dapat dikatakan bahwa ada peningkatan dukungan penghargaan responden.

Rata-rata nilai dukungan informasi dan edukasi pada kelompok intervensi pada pengukuran pertama adalah 17,42 dengan standar deviasi 3,063. Pada pengukuran kedua didapat rata-rata nilai dukungan adalah 38,42 dengan standar 1,640. Terlihat mean perbedaan antara pengukuran pertama dan kedua adalah 21.00 dengan standar deviasi 1,423 . Hasil uji statistik didapatkan nilai $\mathrm{p}=$ 0,000 maka dapat disimpulkan ada perbedaan signifikan antara nilai dukungan informasi dan edukasi keluarga pada pengukuran pertama dan kedua kelompok intervensi. Dari analisis dapat dikatakan bahwa ada peningkatan dukungan informasi dan edukasi responden.

Rata-rata nilai dukungan instrumental pada kelompok inrvensi pada pengukuran pertama adalah 15,63 dengan standar deviasi 3,076. Pada pengukuran kedua didapat rata-rata nilai dukungan adalah 31,58 dengan standar 0,654. Terlihat mean perbedaan antara pengukuran pertama dan kedua adalah 15,95 dengan standar deviasi -2,422. Hasil uji statistik didapatkan nilai $\mathrm{p}=0,000$ maka dapat disimpulkan ada perbedaan signifikan antara nilai dukungan instrumental keluarga pada pengukuran pertama dan kedua kelompok intervensi. Dari analisis dapat dikatakan bahwa ada peningkatan dukungan instrumental responden.

Tabel 7 Distribusi Responden Berdasarkan Rerata Nilai Dukungan Keluarga Pada Kelompok Intervensi dan Kontrol Sebelum-
Sesudah Intervensi Di Surabaya, Tahun 2007 $(\mathrm{n}=48)$

\begin{tabular}{|c|l|c|c|c|c|c|}
\hline No. & $\begin{array}{l}\text { Nilai } \\
\text { Dukungan }\end{array}$ & $\mathbf{N}$ & Mean & SD & SE & $\begin{array}{c}\text { P } \\
\text { value }\end{array}$ \\
\hline 1. & $\begin{array}{l}\text { Kelompok } \\
\text { Intervensi } \\
\text { Pertama } \\
\text { (Pre tes) } \\
\text { Kedua } \\
\text { (Post tes) }\end{array}$ & 24 & 59,50 & 9.250 & 1,914 & 0,000 \\
\hline 2. & $\begin{array}{l}\text { Kelompok } \\
\text { Kontrol } \\
\text { Pertama } \\
\text { (Pre tes) } \\
\text { Kedua } \\
\text { (Post tes) }\end{array}$ & 24 & 59,04 & 9,038 & 1,845 & 0,863 \\
\hline
\end{tabular}

Rata-rata nilai dukungan pada kelompok intervensi pada pengukuran pertama adalah 59,50 dengan standar deviasi 9,250. Pada pengukuran kedua didapat rata-rata nilai dukungan adalah 136,83 dengan standar deviasi 2,899. Terlihat mean perbedaan antara pengukuran pertama dan kedua adalah 77,33 dengan standar deviasi -6,351. Hasil uji statistik didapatkan nilai $\mathrm{p}=0,000$ maka dapat disimpulkan ada perbedaan signifikan antara nilai dukungan keluarga pada pengukuran pertama dan kedua kelompok intervensi. Dari analisis dapat dikatakan bahwa ada peningkatan dukungan responden setelah dilakukan intervensi terapi keluarga.

Pada tabel 5.7 juga menunjukkan rata-rata nilai dukungan pada kelompok kontrol pada pengukuran pertama (pre test) adalah 59,04 dengan standar deviasi 9,038. Pada pengukuran kedua (post test) didapat rata-rata nilai dukungan adalah 58,83 dengan standar deviasi 9,416. Terlihat mean perbedaan antara pengukuran pertama dan kedua adalah $-0,21$ dengan standar deviasi 0,378 . Hasil uji statistik didapatkan nilai $\mathrm{p}=0,863$ maka dapat disimpulkan tidak ada perbedaan yang signifikan antara nilai dukungan keluarga pada pengukuran pertama (pre test) dan kedua (post test) pada kelompok kontrol, dari analisis dapat dikatakan bahwa tidak ada peningkatan dukungan responden yang tidak dilakukan intervensi terapi keluarga.

Nilai dukungan dikategorikan berdasarkan nilai mean. Jika mean dikatakan tidak mendukung dan jika nilai lebih besar dari mean dikatakan keluarga mendukung. Distribusinya dapat dilihat pada tabel 5.8. 
Tabel 8 Distribusi Responden Berdasarkan Rata-rata Dukungan Nilai Dukungan Keluarga Sebelum-Sesudah Intervensi Pada Kelompok Intervensi dan Kontrol Di Surabaya, Tahun 2007 $(\mathrm{n}=48)$

\begin{tabular}{|c|l|c|c|c|c|c|}
\hline No & \multicolumn{1}{|c|}{ Nilai Dukungan } & N & Mean & $\begin{array}{c}\text { Standar } \\
\text { deviasi }\end{array}$ & SE & p value \\
\hline 1. & Pengukuran Pertama (Pre tes) & & & & & \\
& Intervensi & 24 & 59,50 & 9.250 & 1,888 & 0,852 \\
& Kontrol & 24 & 59,04 & 9,038 & 1,845 & \\
\hline 2. & Pengukuran Kedua (Post tes) & & & & & \multirow{2}{*}{$\begin{array}{c} \\
\text { Intervensi }\end{array}$} \\
& Kontrol & 24 & 136,83 & 2,899 & 0,592 & 0,001 \\
\hline
\end{tabular}

Rata-rata nilai dukungan responden pada pengukuran pertama (pre tes) kelompok intervensi adalah 59,50 dengan standar deviasi 9,250. Pada kelompok kontrol didapat rata-rata nilai dukungan adalah 59,04 dengan standar deviasi 9,038. Terlihat mean perbedaan pengukuran pertama antara kelompok intervensi dan kelompok kontrol adalah 0,46 dengan standar deviasi 0,212. Hasil uji statistik didapatkan nilai $\mathrm{p}=0,852$ maka dapat disimpulkan tidak ada perbedaan signifikan antara nilai pengukuran pertama dukungan keluarga pada kelompok intervensi dan kelompok kontrol. Dari analisis dapat dikatakan bahwa tidak ada peningkatan dukungan responden.

Rata-rata nilai dukungan responden pada pengukuran kedua (post tes) kelompok intervensi adalah 136,83 dengan standar deviasi 2,899. Pada kelompok kontrol didapat rata-rata nilai dukungan pengukuran kedua adalah 54,83 dengan standar deviasi 9,416. Terlihat mean perbedaan pengukuran kedua (post test) antara kelompok intervensi dan kelompok kontrol adalah 78 dengan standar deviasi -6,517. Hasil uji statistik didapatkan nilai $\mathrm{p}=0,001$ maka dapat disimpulkan ada perbedaan signifikan antara nilai pengukuran kedua dukungan keluarga pada kelompok intervensi dan kelompok kontrol. Dari analisis dapat dikatakan bahwa ada peningkatan dukungan responden setelah dilakukan intervensi terapi keluarga.

\section{Pengaruh Jumlah Interaksi Terapi Keluarga Terhadap Dukungan Keluarga}

\section{Dalam Merawat Klien Dengan masalah Perilaku Kekerasan.}

Tabel 9 Distribusi Responden Berdasarkan Rata-Rata Jumlah Interaksi Dengan Keluarga Sesudah Intervensi Pada Kelompok Intervensi dan Kontrol Di Surabaya, Tahun 2007 (n=48)

\begin{tabular}{|c|c|c|c|c|c|}
\hline $\begin{array}{c}\text { Nilai } \\
\text { Dukungan }\end{array}$ & $\mathbf{N}$ & Mean & SD & SE & $\begin{array}{c}\mathbf{p} \\
\text { value }\end{array}$ \\
\hline $\begin{array}{l}\text { Jumlah } \\
\text { Interaksi } \\
3 \text { kali } \\
\text { kunjungan/ } \\
\text { Interaksi } \\
4 \text { Kali } \\
\text { kunjungan/ } \\
\text { Interaksi }\end{array}$ & 16 & $\begin{array}{r}135,63 \\
137,44\end{array}$ & $\begin{array}{l}3,249 \\
2,607\end{array}$ & $\begin{array}{l}1,149 \\
0,652\end{array}$ & 0,153 \\
\hline
\end{tabular}

Jumlah responden yang dikunjungi 3 kali sebanyak 8 responden, dengan nilai rata-rata adalah 135,63 dengan standar deviasi 3,249. Sedangkan responden yang 4 kali dikunjungi memiliki nilai rata-rata 137,44 dengan standar deviasi 2,607.

Terlihat mean perbedaan pengukuran antara kelompok yang 3 kali interaksi dan kelompok yang 4 kali interaksi adalah -1,81 dengan standar deviasi 0,642. Hasil uji statistik didapatkan nilai $\mathrm{p}=0,153$ maka dapat disimpulkan tidak ada perbedaan signifikan antara nilai kelompok yang mendapat 3 kali interaksi dengan kelompok yang 4 kali interaksi. Dari analisis dapat dikatakan bahwa tidak ada pengaruh antara jumlah interaksi dengan dukungan keluarga. 


\section{Pembahasan \\ Pengaruh Terapi Keluarga Terhadap Dukungan Keluarga Dalam Merawat Klien Dengan Masalah Perilaku Kekerasan.}

Hasil analisis bivariat, menunjukkan bahwa terdapat perbedaan yang signifikan rata-rata mean dukungan keluarga kelompok intervensi dan kelompok kontrol yang berarti terapi keluarga cukup efektif terhadap peningkatan dukungan keluarga dalan merawat klien dengan masalah perilaku kekerasan hal ini bertentangan dengan pernyataan Denis (1991) yang menyatakan bahwa keluarga memiliki anggota keluarga gangguan jiwa tidak hanya menghadapi suatu beban emosional tetapi juga adanya risiko penyakit fisik yang cukup tinggi. Beberapa keluarga dengan anggota keluarga yang mengalami masalah gangguan jiwa, merasa tidak mampu untuk melakukan fungsi kesehatan keluarga. Mereka akan menghentikan perawatan atau pengobatan disebabkan banyak faktor antara lain adalah ekonomi dan psikologis mereka yang kurang siap menerima kondisi pasien.

Kemarahan/perilaku kekerasan dapat dilakukan karena seseorang karena merasa tertekan/stress, kecemasan, harga diri rendah, dan adanya perasaan bersalah. Respons terhadap marah dapat diekspresikan secara responsif secara eksternal melalui perilaku kekerasan, dan juga dikatakan salah datu faktor predisposisi perilaku kekerasan adalah faktor psikologis, yang disebabkan hubungan yang tidak sportif, kehidupan yang berorientasi pada diri sendiri, kegagalan yang dialami, adanya penguatan perilaku kekerasan, korban perilaku kekerasan dan terpapar perilaku kekerasan, dan faktor sosial budaya, diantaranya ketidakmampuan memenuhi kebutuhan hidup, bermasalah dalam perilaku, keluarga dengan single parent, tidak memiliki pekerjaan, gangguan hubungan interpersonal, serta struktur keluarga dan kontrol sosial (Stuart Laraia, 2005), ditambahkan menurut Mohr (2006), faktor yang pencetus perilaku kekerasan adalah faktor dari diri klien (inpatien), faktor dari luar diri klien (out patient), demografi sosial dan dari faktor keluarga sehingga dapat dipahami bila keluarga merasa tidak mampu mengatasi perilaku klien.
Faktor pencetus perilaku kekerasan juga dapat disebabkan karena klien atau individu tidak dapat melampaui delapan tahap perkembangan dengan tugas-tugas perkembangan psikologis yang bersifat berurutan dan bergantung pada keberhasilan penyelesaian sebelumnya seperti yang diungkapkan dalam teori perkembangan psikososial Erikson yang mengatakan individu yang gagal menyelesaikan tugas perkembangan psikososial pada usia yang seharusnya maka akan mengganggu perkembangan selanjutnya. (Boyd dan Nihart, 1998 dan Mohr, 2006), dapat juga disebabkan kegagalan menjalankan tahaptahap perkembangan keluarga. (Duvall, 1977, dalam Shives 1998).

Tindakan keperawatan pada klien dengan masalah perilaku kekerasan dapat diberikan pada klien dan juga pada keluarga yang diharapkan setelah mendapatkan terapi keluarga dapat memahami keadaan klien dan dapat memberikan dukungan dalam perawatan klien yang diantaranya adalah merawat klien dengan masalah perilaku kekerasan.

Dukungan keluarga sangat penting untuk keberhasilan rehabilitasi dan pemulihan seseorang dengan gangguan jiwa, Bomar (2004) mengatakan bahwa dukungan keluarga adalah suatu bentuk perilaku melayani yang dilakukan oleh keluarga, baik dalam bentuk dukungan emosional (perhatian, kasih sayang, empati), dukungan penghargaan (menghargai, umpan balik), dukungan informasi (saran, nasehat, informasi), maupun dalam bentuk dukungan instrumental (bantuan tenaga, dana dan waktu).

Dari hasil analisa bivariat dengan uji dependen sample t-tes (paired t-tes) menunjukkan bahwa perbedaan rata-rata nilai dukungan emosi pada pengukuran pertama (pre test) dan pengukuran kedua (post test) pada kelompok intervensi adalah 21,45 dengan standar deviasi $-1,851 \mathrm{n}$, dengan nilai $\mathrm{p}=0,001$ maka dapat disimpulkan ada perbedaan signifikan antara nilai dukungan emosi keluarga pada pengukuran pertama dan kedua kelompok intervensi. Dari analisis dapat dikatakan bahwa ada peningkatan dukungan emosi keluarga yang mendapatkan terapi keluarga.

Keluarga dengan kemampuan merawat yang memadai, tentunya akan sangat menunjang 
bagi pasien dalam mengembangkan kemampuannya, tetapi dengan mendapatkan terapi keluarga, dapat meningkatkan kemampuan keluarga memberikan dukungan pada klien secara emosional karena terapi keluarga (Family therapy) adalah suatu tehnik yang digunakan untuk sebuah pendekatan psikoterapi yang membantu anggota keluarga mencapai pengertian yang mendalam dalam mengatasi permasalahan mereka dan merubah perilaku serta emosi dari yang disfungsi ke arah yang lebih sehat. Sesuai juga dengan salah satu pendekatan Menurut Jones (1980, dalam Shives, 1998) yaitu pendekatan Bowen (Murray Bowen's). Pendekatan ini memandang keluarga sebagai kesatuan dari sistem emosional dan sistem hubungan. Terapis meyakini perilaku individu merupakan suatu respon yang mempengaruhi perilaku anggota keluarga lainnya.

Dari hasil analisa bivariat dengan uji dependen sample t-tes (paired t-tes) menunjukkan bahwa perbedaan rata-rata nilai dukungan penghargaan pada pengukuran pertama (pre test) dan pengukuran kedua (post test) pada kelompok intervensi adalah 18,92 dengan standar deviasi -2,037, dengan nilai $\mathrm{p}=0,000$ maka dapat disimpulkan ada perbedaan signifikan antara nilai dukungan penghargaan keluarga pada pengukuran pertama dan kedua kelompok intervensi. Dari analisis dapat dikatakan bahwa ada peningkatan dukungan penghargaan keluarga yang mendapatkan terapi keluarga.

Menurut Shives (1998) keluarga merupakan bagian integral dari masyarakat, mereka terdiri dari dua atau lebih orang dan meliputi anak-anak. Semua anggota keluarga saling mempengaruhi satu dan lainnya melalui interaksi dan saling memberikan support dalam memperlihatlkan fungsi dasar yang perlu untuk kesejahteraan keluarga. Dengan latar belakang keluarga, maka anggota akan belajar bagaimana berhubungan dan berkomunikasi dengan yang lainnya, didukung dengan Chafetz,.at.al (1991, dalam Struat \& Sundeen, 1995) yang menyatakan bahwa dukungan penghargaan atau timbal balik dari keluarga kepada klien sangat penting dilakukan dalam upaya meningkatkan semangat, motivasi, dan peningkatan harga diri klien, sehingga dapat mempengaruhi pembentukan perilaku yang adaptif dari klien dalam upaya peningkatan kesehatannya.

Demikian juga dengan keluarga klien yang mendapat terapi keluarga akan merasakan pentingnya penghargaan yang harus kita berikan pada anggota keluarga, karena itu merupakan bagian dari terapi keluarga, seperti yang diungkapkan Boyd dan Nihart (1998) bahwa aktifitas terapi keluarga yaitu mendiskusikan rencana terapi dengan keluarga, menentukan area permasalahan atau konflik dan mengamati anggota keluarga yang dapat membantu, menggunakan riwayat keluarga untuk mendorong diskusi keluarga, mengajak keluarga untuk berpartisipasi dalam kegiatan terapi, dan memberi reward positif, dan membantu keluarga untuk menyusun kembali tujuan untuk membantu mengatasi bila ada perilaku tidak sesuai dari anggota keluarga.

Dukungan informasi keluarga merupakan suatu dukungan atau bantuan yang diberikan oleh keluarga dalam bentuk memberikan saran atau masukan, nasehat atau arahan, dan memberikan informasi-informasi penting yang sangat dibutuhkan klien dalam meningkatkan status kesehatannya (Bomar, 2004). Salah satu bentuk dukungan adalah dukungan informasi. Pemberian informasi dapat membimbing dan meningkatkan kemampuan klien dengan masalah gangguan jiwa atau masalah perilaku kekerasan, mengingatkan hal-hal yang dapat dilakukan oleh klien sehingga klien tetap dapat hidup produktif dalam keadaannya. Intervensi yang dapat dilakukan pada keluarga sebagai pemberi perawatan diantaranya adalah pemberian informasi keperawatan dan kesehatan melalui pendidikan kesehatan sehingga keluarga dapat mengaplikasikan konsep yang yang dimiliki untuk merawat anggota keluarga yang sakit. Fungsi ini dapat dicapai melalui interaksi dan hubungan yang harmonis sesama anggota keluarga, sehingga masing-masing anggota keluarga mampu menerima suatu tugas dan peran dalam keluarga dengan baik.

Hasil analisa bivariat dengan uji dependen sample t-tes (paired t-tes) menunjukkan bahwa dukungan instrumental juga menunjukkan bahwa ada perbedaan rata-rata nilai dukungan instrumental pada pengukuran pertama (pre test) dan pengukuran kedua (post test) pada kelompok intervensi adalah 15,95 dengan standar deviasi -2,422, dengan 
nilai $\mathrm{p}=0,000$ maka dapat disimpulkan ada perbedaan signifikan antara nilai dukungan instrumental keluarga pada pengukuran pertama dan kedua kelompok intervensi. Dari analisis dapat dikatakan bahwa ada peningkatan dukungan instrumental keluarga yang mendapatkan terapi keluarga.

Dukungan instrumental keluarga merupakan suatu dukungan atau bantuan penuh keluarga dalam bentuk memberikan bantuan tenaga, dana, maupun meluangkan waktu untuk membantu atau melayani dan mendengarkan klien dalam menyampaikan perasaannya (Bomar, 2004). Pentingnya pemberian terapi keluarga terhadap keluarga dengan klien masalah perilaku kekerasan, untuk dapat meningkatkan kemandirian klien dalam kehidupannya, didukung juga oleh Chafetz,.at.al (1991, dalam Struat \& Sundeen, 1995) yang menyatakan bahwa dengan adanya dukungan instrumental dari keluarga memungkinkan klien dapat beraktifitas dan memenuhi kebutuhan aktifitasnya secara optimal.

Untuk mengetahui adanya perbedaan dukungan sebelum dan sesudah perlakuan terapi keluarga, dilakukan analisis dengan uji dependen sample t-test (paired t-test). Hasil analisis dengan uji dependen sample t-test (paired t-test) perbedaan rata-rata nilai dukungan responden pada pengukuran kedua (post tes) kelompok intervensi dan kelompok kontrol adalah 78 dengan standar deviasi 6,517 dengan nilai $\mathrm{p}=0,001$, maka dapat disimpulkan ada perbedaan signifikan antara nilai pengukuran kedua dukungan keluarga pada kelompok intervensi dan kelompok kontrol. Dari analisis dapat disimpulkan bahwa ada peningkatan dukungan responden setelah dilakukan intervensi terapi keluarga.

Dalam pelaksanaan terapi keluarga menurut Boyd dan Nihart (1998) ada beberapa aktivitas perawat dalam kegiatan terapi keluarga yaitu mendiskusikan rencana terapi dengan keluarga, menentukan area permasalahan atau konflik dan mengamati anggota keluarga yang dapat membantu, menggunakan riwayat keluarga untuk mendorong diskusi keluarga, mengajak keluarga untuk berpartisipasi dalam kegiatan terapi, memfasilitasi diskusi anggota keluarga dengan prioritas masalah yang disepakati, memberi penjelasan dan memberi reward positif, dan membantu keluarga untuk menyusun kembali tujuan untuk membantu mengatasi bila ada perilaku tidak sesuai dari anggota keluarga, kegiatan dan aktivitas tersebut yang dapat meningkatkan pemahaman dan motivasi keluarga memberi dukungan dalam merawat klien dengan masalah perilaku kekerasan.

Intervensi terapi keluarga menggunakan fase atau tahap-tahap yang harus dilalui secara berurutan, tiga tahap utama dalam terapi keluarga menurut Shives (1988) yaitu: fase interview awal, intervensi atau fase kerja, dan fase terminasi, setiap fase dapat dilakukan beberapa sesi, dan masing-masing sesi memerlukan waktu paling lama dua jam. Suatu jadwal yang fleksibel diperlukan jika keadaan geografis dan personal menimbulkan kesulitan. Tahap-tahap terapi keluarga dan jadwal terapi yang fleksibel juga merupakan salah satu faktor yang mungkin mempengaruhi keberhasilan terapi keluarga.

\section{Simpulan dan Saran}

Dengan dilakukannya terapi keluarga pada keluarga yang memiliki anggota yang mengalami masalah perilaku kekerasan, diperoleh hasil 1) Dukungan emosi keluarga dalam merawat klien dengan masalah perilaku kekerasan yang diberikan terapi keluarga meningkat setelah diberi terapi keluarga, kondisi ini menunjukkan bahwa intervensi terapi keluarga efektif dalam meningkatkan dukungan emosi keluarga dalam merawat klien dengan masalah perilaku kekerasan. 2) Dukungan penghargaan keluarga dalam merawat klien dengan masalah perilaku kekerasan yang diberikan terapi keluarga meningkat setelah diberi terapi keluarga, kondisi ini menunjukkan bahwa intervensi terapi keluarga efektif dalam meningkatkan dukungan penghargaan keluarga dalam merawat klien dengan masalah perilaku kekerasan. 3) Dukungan informasi dan edukasi keluarga dalam merawat klien dengan masalah perilaku kekerasan yang diberikan terapi keluarga meningkat setelah diberi terapi keluarga, kondisi ini menunjukkan bahwa intervensi terapi keluarga efektif dalam meningkatkan dukungan informasi dan edukasi keluarga dalam merawat klien dengan masalah perilaku kekerasan. 4) Dukungan instrumental keluarga dalam merawat klien dengan masalah perilaku kekerasan yang diberikan terapi keluarga meningkat setelah 
diberi terapi keluarga, kondisi ini menunjukkan bahwa intervensi terapi keluarga efektif dalam meningkatkan dukungan instrumental keluarga dalam merawat klien dengan masalah perilaku kekerasan. 5) Terdapat perbedaan dukungan keluarga pada kelompok intervensi sebelum dan setelah dilakukan terapi keluarga. Dukungan keluarga dalam merawat klien dengan masalah perilaku kekerasan yang diberikan terapi keluarga meningkat setelah diberi terapi keluarga, kondisi ini menunjukkan bahwa intervensi terapi keluarga efektif dalam meningkatkan dukungan keluarga dalam merawat klien dengan masalah perilaku kekerasan. 6) Tidak terdapat perbedaan dukungan keluarga hasil pengukuran pertama dan kedua pada kelompok kontrol. Dukungan keluarga dalam merawat klien dengan masalah perilaku kekerasan yang tidak diberikan terapi keluarga tidak mengalami perubahan. 7) Terdapat perbedaan dukungan keluarga pada kelompok intervensi dan kelompok kontrol setelah dilakukan terapi keluarga pada kelompok intervensi. Dukungan keluarga dalam merawat klien dengan masalah perilaku kekerasan yang mendapatkan terapi keluarga meningkat setelah diberi terapi keluarga, kondisi ini menunjukkan bahwa intervensi terapi keluarga efektif dalam meningkatkan dukungan keluarga dalam merawat klien dengan masalah perilaku kekerasan. Sehingga di saran 1) Bagi Pelayanan Keperawatan bagi Depkes RI: bekerjasama dengan pihak daerah yang telah mengembangkan program pelayanan kesehatan jiwa dalam pembuatan kebijakan yang terkait dengan pelayanan kesehatan jiwa di Indonesia dengan fokus preventif dan kuratif. Bagi Dinas Kesehatan Kota Surabaya mengaktifkan kembali program kesehatan jiwa masyarakat yang telah ada untuk mendukung pelayanan kesehatan jiwa di Kota Surabaya dan menjadi masukan dalam mengambil kebijakan yang mendukung pelayanan kesehatan jiwa masyarakan dengan perencanaan pengadaan Perawat Kesehatan Jiwa di Masyarakat (CMHNCommunity Mental Health Nursing). Bagi Puskesmas di wilayah kerja Dinas kesehatan Kota Surabaya mendukung keberlanjutan program kesehatan jiwa di masyarakat dengan merencanakan asuhan keperawatan jiwa masyarakat yang komprehensif. Bagi Komunitas: mengembangkan kelompokkelompok sehat jiwa bagi untuk dapat meningkatkan kemampuan dukungan bagi keluarga dengan klien gangguan jiwa. Bagi keluarga yang anggota keluarganya mengalami gangguan jiwa: meningkatkan kemampuan keluarga dalam merawat dan mencari bantuan untuk anggota keluarga yang mengalami gangguan jiwa.

Depkes. (1992). Undang - undang Republik Indonesia N : 23 Tahun 1992 tentang Kesehatan, Jakarta : Depkes.

(1993). Pedoman Penggolongan Diagnosa Gangguan Jiwa di Indonesia III. Jakarta : Direktorat Jenderal Pelayanan Medik Depkes.

Febriani. 2006. Penderita Gangguan Jiwa

Terus Meningkat.

http://www.pikiran-

rakyat.com/prprint.php?mib=beritade tail\&id $=49178$ diperoleh tanggal 3 Juni 2009.

. (2009). What Is Schizophrenia

?, NARSAD Researcher, http://www.narsad.org/dc/schizophre nia/index.html diperoleh tanggal 3 Juni 2009.

Hawari,D. (2001). Pendekatan holistik pada gangguan jiwa skizoprenia. Jakarta: Fakultas Kedokteran Universitas Indonesia.

Kaplan,H.I., Sadock,B.J., Grebb,J.A. (2002). Sinopsis Psikiatri. Edisi Ketujuh. Jakarta: Binarupa Aksara . (2006). Modul IC CMHN : Manajemen kasus gangguan jiwa dalam keperawatan kesehatan jiwa komunitas. Jakarta: WHO-FIK UI

Keliat, B.A., Akemat.(2005). Keperawatan Jiwa: Terapi Aktifitas Kelompok, Jakarta: EGC.

Tim Pengembangan CMHN (2006). Modul IC-CMHN: Manajemen Keperawatan Kesehatan Jiwa Komunitas: Desa Siaga Sehat JIwa. Jakarta : World Health Organization (WHO) Perwakilan Indonesia \& Fakultas Ilmu Keperawatan UI. 